\title{
Controlling factors in planktonic communities over a salinity gradient in high-altitude lakes
}

\author{
Frau Diego $^{1 *}$, Battauz Yamila ${ }^{1}$, Mayora Gisela ${ }^{1}$ and Marconi Patricia ${ }^{2}$ \\ 1 Instituto Nacional de Limnología (INALI), Ciudad Universitaria, Paraje El Pozo S/N, (3000) Santa Fe, Argentina \\ 2 Fundación YUCHAN, Mariano Moreno 1950 (A4401XAK), Villa San Lorenzo, Salta, Argentina
}

Received 5 December 2014; Accepted 7 August 2015

\begin{abstract}
This study aimed to determine the factors affecting plankton structure along a salinity gradient during the summer in high-altitude endorheic lakes in Catamarca Province (Argentina). During the summer 2013, eight lakes located between 3000 and 4300 meters above sea level were sampled in a 6-day period being analysed plankton, limnological variables and flamingo abundance. Principal Component Analysis explained $80 \%$ of the system variability, permitting lakes to be ordered by salinity: subhaline $(\mathrm{SH})$, hypohaline $(\mathrm{HH})$ and mesohaline $(\mathrm{MH})$. A total of 101 phytoplankton taxa were registered, having Bacillariophyceae the highest richness (43 species registered). HH lakes were dominated by Bacillariophyceae (between 65 and 100\%), while Chlorophyceae and Euglenophyceae were more abundant in SH and MH lakes. Zooplankton was poorly represented in richness (only 21 species were registered). $\mathrm{MH}$ lakes were dominated by Copepoda ( $>85 \%$ of total abundance) and $\mathrm{HH}$ lakes by Rotifera ( $>51 \%$ of total abundance). It was not found a clear pattern in SH lakes. The redundancy analysis explained $70.7 \%$ of phytoplankton variability and $75.7 \%$ of zooplankton variability. Bacillariophyceae presence was associated with availability of dissolved silica (Si), while Euglenophyceae and Chlorophyceae were associated with a higher nitrogen:phosphorus ratio. Cladocera and Copepoda abundance were linked to Euglenophyceae abundance and the area of lakes while Rotifera displayed a positive relation with the concentration of dissolved organic matter. We conclude that both phytoplankton and zooplankton abundance are mainly controlled by Bottom-Up forces including dissolved Si for Bacillariophyceae, and availability of Euglenophyceae for zooplankton while salinity and altitude have an effect on plankton richness distribution.
\end{abstract}

Key words: Phytoplankton / zooplankton / Bottom-Up / Top-Down / high-altitude salt lakes

\section{Introduction}

In recent decades, high-altitude lakes have been impacted by several human activities, such as changes in land use and mining which cause nutrient enrichment, organic pollution and an increased heavy metal load (Tolotti et al., 2006). In the same period, high mountain lakes have gained importance as biodiversity reserves and as freshwater resources (Locascio de Mitrovic et al., 2005). Despite the fact that only one-tenth of humanity lives in mountain areas these lakes provide water to a much larger percentage of human population. In the future, the importance of this resource may increase further considering the evidence for climate change and the predicted effects on precipitation patterns in large parts of the world (Meehl et al., 2005).

\footnotetext{
*Corresponding author: diegofrau@gmail.com
}

In this scenario, high-altitude lakes tend to become salt lakes since low rate of rainfalls and a high rate of evaporation take place in these environments, and determine saline accumulation (Hammer, 1986; Drago and Quirós, 1996). The formation of salt lakes is also favoured in endorheic drainage basins that are located in semi-arid and sub-humid climates where evaporation exceeds precipitation (Williams et al., 1990). Hammer (1986) classified lakes according to their salinity: subhaline (SH; 0.5-3 g.L $\left.{ }^{-1}\right)$, hypohaline (HH; 3-20 g.L ${ }^{-1}$ ), mesohaline $\left(\mathrm{MH} ; 20-50\right.$ g.. $\left.\mathrm{L}^{-1}\right)$ and hyperhaline $\left(>50\right.$ g. $\left.\mathrm{L}^{-1}\right)$. Saline lakes occur widely across all continents, including Antarctica and are often dominant landscape features, catching approximately $80 \%\left(85 \times 10^{3} \mathrm{~km}^{3}\right)$ of total inland water (Williams, 2002).

Due to the extreme environmental conditions (low temperature, strong irradiance and scarce nutrients), highaltitude lakes tend to have simple food webs and react 
more rapidly and more sensitively to environmental changes than other lakes (Psenner, 2002). In salt lakes where plankton is adapted to high ionic concentrations, factors such as habitat stability, predation and resource availability could be more important in the structuration of this community (Timms, 1993; Cooper and Wissel, 2012).

Historically, high-altitude salt lakes have received less attention than other kind of water systems. This is likely linked to the difficulty obtaining samples, the variety of morphological and hydrological characteristics, the complexity of the geology, and the variety of basins and their water bodies (Williams et al., 1990; Álvarez Blanco et al., 2011). The understanding of plankton in high-altitude lakes, provides us an insight into the ecology of these water systems, and could be used in the future, for the conservation and management of these valuable and climatically sensitive environments (Tolotti et al., 2006). In South America, where these lakes are mainly distributed to high altitudes, studies related to plankton ecology are scarce and mostly describe its composition (Locascio de Mitrovic et al., 2005; Seeligmann et al., 2008; Maidana et al., 2009; Mirande and Traccana, 2009; Álvarez Blanco et al., 2011) with some exceptions like Rejas et al. (2012) who demonstrate the importance of nutrient limitation for high-altitude phytoplankton assemblages in an experiment. These studies are important contribution to the description of the Flora and Fauna of this area, but they do not provide information about the factors which regulate plankton abundance and species richness, or even if those regulating factors are the same than freshwater water bodies of lowland areas.

In freshwater environments, factors such as nutrient availability, especially nitrogen $(\mathrm{N})$ and phosphorus $(\mathrm{P})$ and zooplankton-fish interaction are widely recognized as controlling factors of plankton composition and abundance. In high-altitude salt lakes, other variables such as silica ( $\mathrm{Si}$ ) concentration, dissolved organic matter (DOM) availability and bird filter-feeding activity could be other important regulating factors that have not been explored yet. Based on this knowledge, we aimed to analyse those factors that control plankton richness and abundance in a salinity gradient in high-altitude lakes in Northwestern Argentina. We predict that altitude and salinity determine what species can survive in these environments, being abundance mainly regulated by Bottom-Up and TopDown forces.

\section{Material and methods}

\section{Study area}

We surveyed lakes located between latitudes $25^{\circ} 0^{\prime} 0^{\prime \prime}$ and $28^{\circ} 0^{\prime} 0^{\prime \prime}$ south, and longitudes $67^{\circ} 0^{\prime} 0^{\prime \prime}$ and $69^{\circ} 0^{\prime} 0^{\prime \prime}$ west, which display a predominant volcanic morphology and are located between 3000 and 4300 meters above sea level (m.a.s.1.), with numerous cones and wide warehouses of lava and pyroclastic material. The climate is cold and dry,

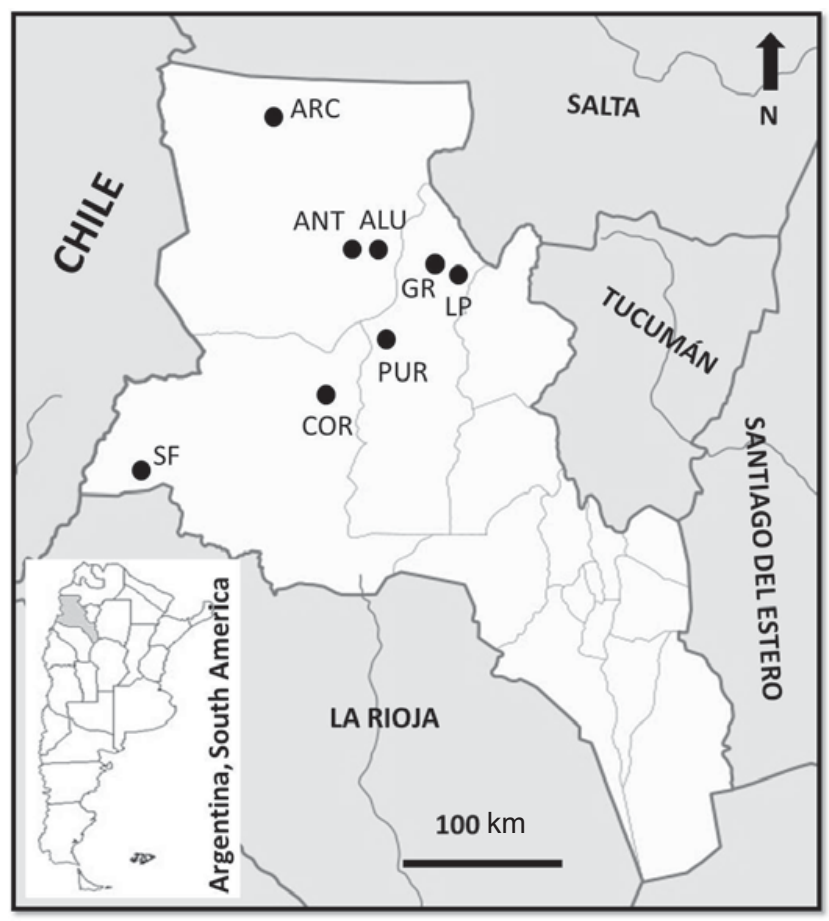

Fig. 1. Study area: locations of the shallow lakes sampled are indicated. San Francisco (SF), Cortaderas (COR), Purulla (PUR), Las Peñas (LP), Grande (GR), Alumbrera (ALU), Antofagasta (ANT), Archibarca (ARC).

with temperatures below $0{ }^{\circ} \mathrm{C}$ most of the year and a rainfall rate lower than $150 \mathrm{~mm}$.year ${ }^{-1}$ (Marconi, 2010). Most of these lakes are shallow, commonly lower than $1 \mathrm{~m}$ depth, and tend to become partially or completely frozen during winter (Boyle et al., 2004). All of them belong to endorheic basins where water comes mainly from melt water infiltration of the surrounding mountains, leaving the drainage system only by evaporation. There are no fish, and aquatic vegetation is rare to non-existent. The most conspicuous fauna in these lakes are three species of flamingo (Phoenicoparrus andinus (Philippi), Phoenicoparrus jamesi (Sclater) and Phoenicopterus chilensis (Molina)) which live in this area during the summer season and are the main predators of plankton in these environments (Mascitti and Kravett, 2002).

\section{Samplings and laboratory analyses}

In a period of six consecutive days (from February 2 to 7,2013 ) eight lakes with an average depth of $0.11 \pm 0.5 \mathrm{~m}$ were sampled: Grande, Archibarca, Purulla, Las Peñas, Antofagasta, Alumbrera, San Francisco and Cortaderas (Fig. 1). Two replicas were taken at lakes with an estimated area $<50$ ha, while four replicas were taken at lakes with an area $\geq 50$ ha, accounting for a total of 24 samples for phytoplankton and 24 samples for zooplankton density estimation. Density values of each lake were expressed as the mean value accompanied by its variation coefficient $(\mathrm{CV})$ expressed as a percentage. 
For the limnological analyses the measurements made in situ included: temperature $\left({ }^{\circ} \mathrm{C}\right), \mathrm{pH}$, dissolved oxygen (DO in mg. $\mathrm{L}^{-1}$ ) and conductivity $\left(\mathrm{mS} . \mathrm{cm}^{-1}\right.$ ) with the use of HANNA multi-parametric meters, transparency with a Secchi disc (m) and altitude (m.a.s.l.) using an altimeter. Altitude was used as an indicator of ultraviolet (UV) radiation which certainly can affect plankton species composition. The area of lakes was estimated using the method proposed by Dangaus (1976) and the salinity was estimated from conductivity (Conzonno, 2009). Additional samples were taken for chemical analysis. Samples for the determination of nitrate + nitrite $\left(\mathrm{N}-\mathrm{NO}_{3}^{-}+\mathrm{N}-\mathrm{NO}_{2}^{-}\right)$, ammonium $\left(\mathrm{N}-\mathrm{NH}_{4}^{+}\right)$and total nitrogen (TN) were acidified to a $\mathrm{pH}$ less than 2 with concentrated sulphuric acid. Samples for soluble reactive phosphorus (SRP) were preserved by adding $5 \mathrm{mg}$. $\mathrm{L}^{-1}$ of $\mathrm{HgCl}_{2}$. Samples for total phosphorus (TP) and samples for total organic carbon (TOC) were acidified to a $\mathrm{pH}$ less than 2 with concentrated hydrochloric acid and concentrated phosphoric acid, respectively. After chemical preservation, the samples were stored in cool and dark conditions before transportation to the laboratory and subsequent analysis. Samples for the analysis of dissolved $\mathrm{Si}$ and optical properties of the DOM were also collected and preserved in cold and darkness.

Acidified water samples were neutralized in the laboratory. Samples used for the determination of dissolved components were filtered through membrane filters $(0.45 \mu \mathrm{m}$ pore size) reserving a portion of unfiltered sample for determination of TN and TP. N-NO ${ }_{3}^{-}+\mathrm{N}_{-} \mathrm{NO}_{2}^{-}$was estimated by reduction of $\mathrm{N}-\mathrm{NO}_{3}^{-}$with hydrazine sulphate and subsequent colorimetric determination of $\mathrm{N}-\mathrm{NO}_{2}^{-}$ (Hilton and Rigg, 1983), $\mathrm{N}^{-\mathrm{NH}_{4}^{+}}$was determined by the indophenol blue method, SRP by the ascorbic acid method and $\mathrm{Si}$ by the molibdosilicate method. TP was estimated by digestion with potassium persulphate in acidic medium followed by determination of SRP and $\mathrm{TN}$ by digestion with potassium persulphate in alkaline medium followed by determination of $\mathrm{N}-\mathrm{NO}_{3}^{-}+\mathrm{N}-\mathrm{NO}_{2}^{-}$. The methodology proposed in APHA (1992) was followed for each case, and nutrient concentrations were expressed as $\mu \mathrm{M}$. Dissolved inorganic nitrogen (DIN) was expressed as the sum of $\mathrm{N}_{-} \mathrm{NO}_{3}^{-}+\mathrm{N}-\mathrm{NO}_{2}^{-}+\mathrm{N}-\mathrm{NH}_{4}^{+}$and was used to calculate the DIN:SRP ratio. The optical density of filtered samples was determined at 250 and $365 \mathrm{~nm}$ using quartz cuvettes with $1 \mathrm{~cm}$ path length. Absorption coefficients were determined from the optical density at each wavelength according to the method of Kirk (1994):

$$
A \lambda=2.303 D \lambda / r
$$

where $A \lambda$ is the DOM absorption coefficient at wavelength $\lambda, D \lambda$ is the optical density at wavelength $\lambda$, and $r$ is the cuvette path length in m. $A_{250}$ and $A_{365}$ are measures of DOM concentration (Kieffer, 1981; Collier, 1987), being $\mathrm{A}_{250}$ more appropriate for DOM of low molecular weight (Stewart and Wetzel, 1981). The ratio of $A_{250}$ to $A_{365}$ $\left(\mathrm{E}_{2}: \mathrm{E}_{3}\right)$, which increases as the molecular weight of DOM decreases (De Haan and De Boer, 1987), was then calculated. Finally, TOC analyses were made according to the international standard ISO:1999 8245.

Samples of phytoplankton were collected from the subsuperficial region using $100 \mathrm{~mL}$ bottles and then were immediately fixed with $1 \%$ acidified lugol solution. Quantitative sample analysis was carried out in accordance with the Utermöhl (1958) method and the density obtained was expressed as ind. $\mathrm{mL}^{-1}$. For the estimation of zooplankton abundance, between 10 and $30 \mathrm{~L}$ of water, were filtered through a conventional conical plankton net $(50 \mu \mathrm{m})$ with a collector and a $2 \mathrm{~L}$ bucket. The collected material was fixed in situ with $10 \%$ formalin and dyed with erythrosine. The counts of the micro-zooplankton (Rotifera and nauplii) were carried out with a conventional optical microscope, in chambers of the SedgwickRafter type with a capacity of $1 \mathrm{~mL}$. Macro-zooplankton (Cladocera and Copepoda) counts were performed in a Borogov-type counting chamber with a $5 \mathrm{~mL}$ capacity. Density was expressed as ind. $\mathrm{L}^{-1}$. Taxonomic identification was carried out reaching the minimum possible taxonomic level. Phytoplankton taxonomic identifications were based on Van den Hoek et al. (1995). Taxonomic determinations were made following keys and specific bibliography of each algal group such as Krammer and Lange-Bertalot (1991), Zalocar de Domitrovic and Maidana (1997) for Bacillariophyceae, Tell and Conforti (1986) for Euglenophyceae, Komárek and Fott (1983) for Chlorophyceae and Komárek and Anagnostidis (1999, 2005) for Cyanobacteria among other authors and recent revisions. Zooplankton taxonomic identifications were based on Ahlstrom (1940), Koste (1978), Koř́nek (1981, 2002), Korovchinsky (1992) and Alekseev (2002) among others. Each flamingo species $(P$. andinus, $P$. jamesi and $P$. chilensis) was separately counted using telescopes and binoculars (Marconi, 2010).

\section{Statistical analyses}

Lake clusters were made using a principal component analysis (PCA) with all of the environmental and biological variables that were measured. Of the 23 environmental variables considered during this study, only those that presented an acceptable level of correlation with other variables (variance inflation factor, VIF $<20$ ) were used for the analyses (Lepš and Šmilauer, 1998). The resulting lake groups were named according to Hammer's salinity classification (Hammer, 1986) as $\mathrm{HH}, \mathrm{SH}$ and MH lakes. Differences in total plankton abundance (phytoplankton and zooplankton) and by groups (Chlorophyceae, Euglenophyceae, Bacillariophyceae, Cryptophyceae, Cyanobacteria, Rotifera, Cladocera and Copepoda) were analysed using the Kruskal-Wallis (KW test) and Mann-Whitney tests (MW test) as a post hoc test to make comparisons between groups of lakes with a $95 \%$ confidence interval $(\alpha=0.05)$. Differences in the composition of plankton species between lake types were examined using the similarity percentage analysis (SIMPER), comparing species density among lake groups, and using the 
Bray-Curtis method. This analysis was accompanied by a non-parametric multivariate analysis of variance (NPMANOVA) to elucidate if those differences found in the SIMPER analysis were statistically significant. Spearman correlations were made among the different environmental variables and phyto-zooplankton richness, respectively.

Redundancy analysis (RDA) was applied to find those variables with greater influence on plankton structure, since the Detrended Correspondence Analysis revealed that the gradient length of the response data was $<3$ (Lepš and Šmilauer, 1998). Again, only those variables that had an acceptable VIF value were considered in RDA analyses (Lepš and Šmilauer, 1998). Phytoplankton and zooplankton density were used as separately response variables. The explanatory variables were physical-chemical variables, flamingo abundance (the three species separately), Rotifera density and microcrustacean (Cladocera + Copepoda) density for phytoplankton analysis, and physical-chemical variables, flamingo abundance and density of phytoplankton taxonomic groups for zooplankton analysis. All data were log-transformed to stabilize variance and to reduce the influence of dominant taxa on the arrangement, being the standardization carried out by error variance. Additionally, the significance of each variable and the combination of all canonical axes were determined using the Monte Carlo permutation testing (499 permutations). Statistical analyses were made using PAST 2.3 and CANOCO 4.5 software.

\section{Results}

\section{Lakes ordination and environmental characterisation}

PCA analysis showed that ten of the 23 variables were able to explain $80 \%$ of the total variance. The first axis explained $54 \%$ and the second $17 \%$. The analysis revealed three main lake groups that corresponded to a salinity gradient (Fig. 2). Alumbrera, Antofagasta and Cortaderas (SH lakes, $0.5-3$ g. $\mathrm{L}^{-1}$ of salt) were primarily associated with high values of DIN:SRP, greater Secchi depth and higher mean temperature. The second group of lakes was formed by Purulla, San Francisco and Grande ( $\mathrm{HH}$ lakes, 3-20 g.L $\mathrm{L}^{-1}$ of salt) principally characterized by DOM of low molecular weight (high $\mathrm{E}_{2}: \mathrm{E}_{3}$ ), higher $\mathrm{Si}$ concentration, DO and abundance of flamingos ( $P$. andinus and $P$. jamesi). The third group was formed by Archibarca and Las Peñas (MH, 20-50 g. $\mathrm{L}^{-1}$ of salt), and was chiefly characterized by high TOC concentration, altitude and the abundance of $P$. chilensis individuals (especially in Las Peñas Lake). The different physicalchemical values for every single lake are shown in Table 1.

\section{Plankton composition and abundance between lake types}

A total of 101 phytoplankton species were registered in all lakes sampled, being Bacillariophyceae the dominant

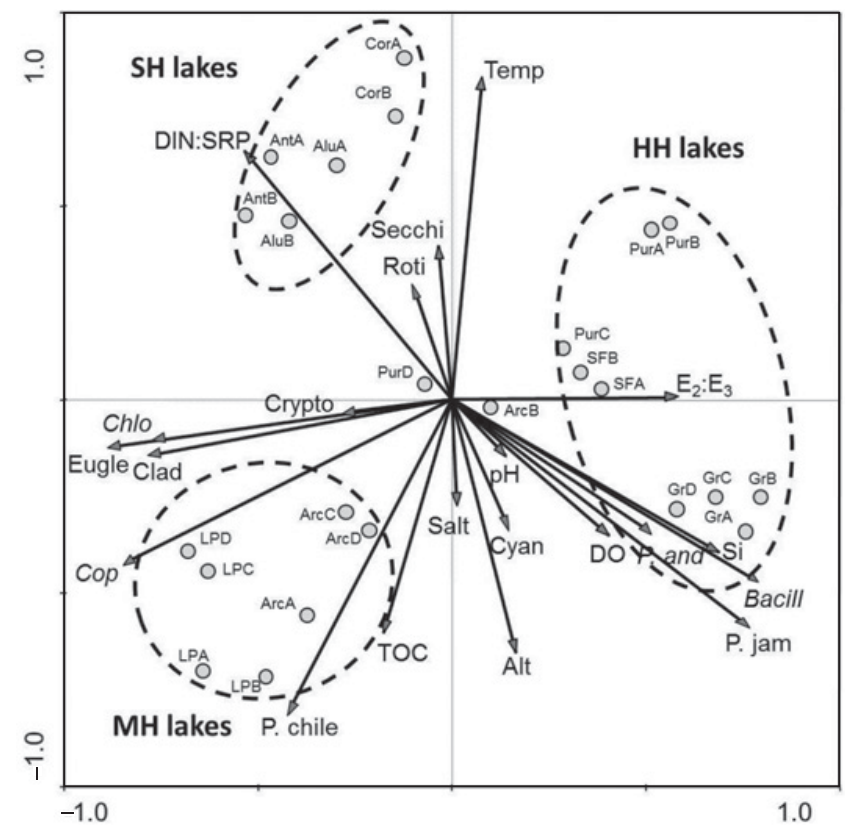

Fig. 2. Biplot of the PCA (1st and 2nd component) showing all sampling points considered with their replicas. Variables used: temperature (Temp), dissolved inorganic nitrogen: soluble reactive phosphorus ratio (DIN:SRP), transparency (Secchi), altitude (Alt), salinity (Salt), total organic carbon (TOC), pH $(\mathrm{pH})$, absorbance ratio $\left(\mathrm{E}_{2}: \mathrm{E}_{3}\right), P$. andinus abundance $(\mathrm{P}$. and $)$, $P$. jamesi abundance (P. jam), dissolved oxygen (DO), $\mathrm{Si}$ concentration (Si), Chlorophyceae (Chlo), Euglenophyceae (Eugle), Cryptophyceae (Crypto), Cyanobacteria (Cyan), Bacillariophyceae (Bacill), Cladocera (Clad), Copepoda (Cop), Rotifera (Roti).

group with 43 species, followed by Chlorophyceae with 34 species, Euglenophyceae (twelve species), Cyanobacteria (ten species) and Cryptophyceae (three species). Bacillariophyceae was dominant in $\mathrm{HH}$ lakes ( $>65 \%$ of total abundance). SH and $\mathrm{MH}$ lakes had a greater distribution of taxa and did not show a clear pattern of dominance by any group. Nonetheless, it is notable that Chlorophyceae and Euglenophyceae were far more abundant in these lakes than in $\mathrm{HH}$ lakes. Cyanobacteria and Cryptophyceae were not well represented in the lakes studied (Fig. 3(a)).

SIMPER analysis demonstrated that differences in species composition between lake types were very important $(>90 \%$ of dissimilarity in all cases) and statistically significant $(P<0.05)$ (Table 2$)$. The group of SH lakes was largely characterized by Lepocinclis sp. (Euglenophyceae) and Oocystis elliptica (Stearn) (Chlorophyceae); the HH group by Bacillariophyceae, principally species of Navicula spp. and Surirella spp., while MH lakes were represented by Trachelomonas volvocina (Ehrenberg), Euglena acus (Müller) (Euglenophyceae) and Cryptomonas ovata (Ehrenberg) (Cryptophyceae). Spearman correlations demonstrated that phytoplankton species richness was negatively associated with altitude (Rho $=-0.58, P=0.003)$ and positively linked with Secchi depth $(\mathrm{Rho}=0.475, P=0.019)$. 


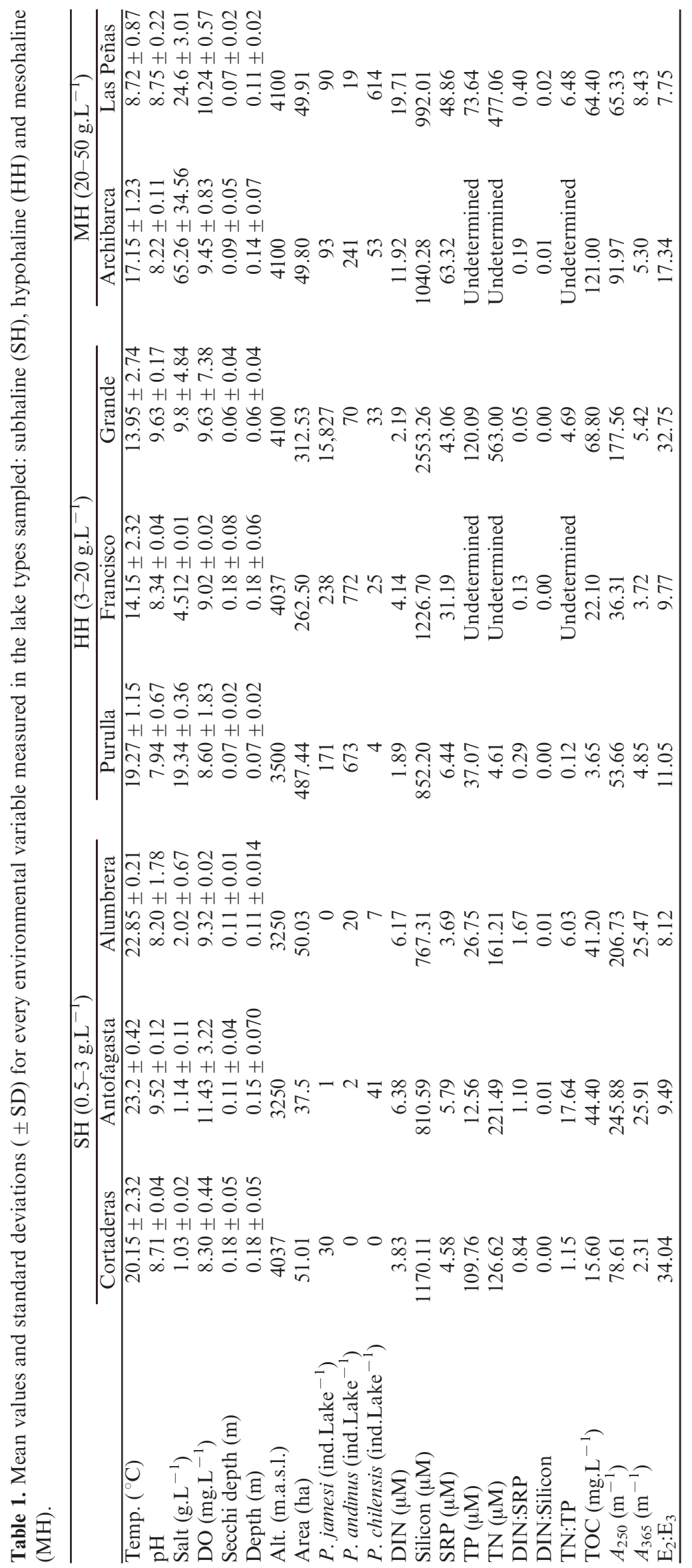




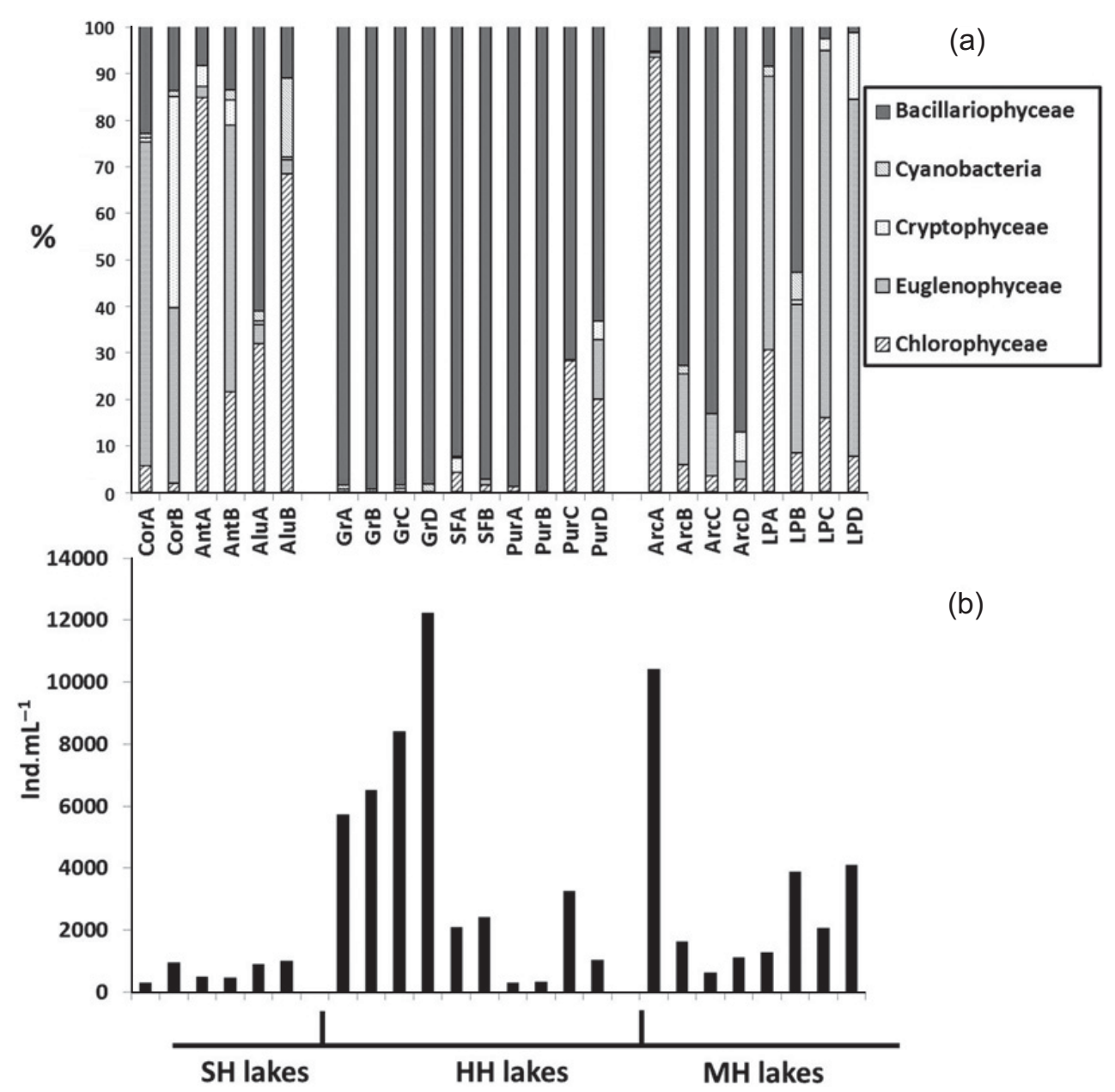

Fig. 3. Percentage of contribution of the different phytoplankton groups (a) and total abundance (ind. $\mathrm{mL}^{-1}$ ) registered in each sampling point (b).

Table 2. Results of SIMPER and NPMANOVA analyses for every lake combination. Subhaline (SH), hypohaline (HH) and mesohaline $(\mathrm{MH})$.

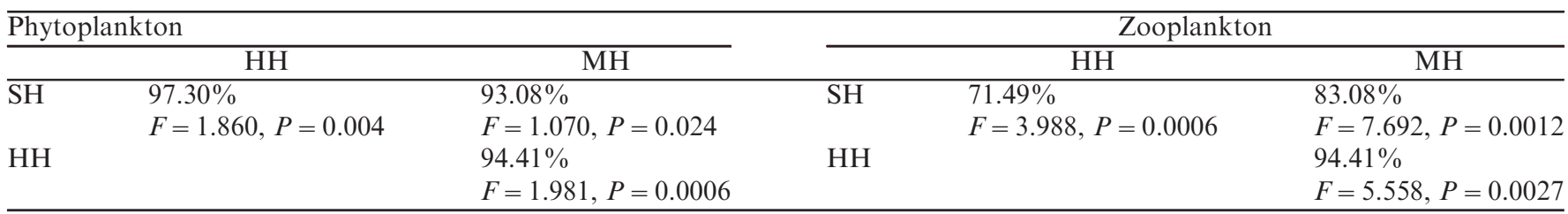

The greatest phytoplankton abundance was registered in $\mathrm{HH}$ and $\mathrm{MH}$ lakes with mean values of 4226 ind. $\mathrm{mL}^{-1}$ $(\mathrm{CV}=92)$ and 3131 ind. $\mathrm{mL}^{-1}(\mathrm{CV}=102)$, respectively. The lowest density was registered in $\mathrm{SH}$ lakes with an average of 683 ind. $\mathrm{mL}^{-1}(\mathrm{CV}=44)$ (Fig. 3(a)). The KW test indicated that these differences were statistically significant $(Z=7.493, P=0.023)$, as were those found between the $\mathrm{SH}-\mathrm{HH}$ and $\mathrm{SH}-\mathrm{MH}$ groups (MW test, $P=0.034$ and 0.008 , respectively). The high coefficients of variation observed in $\mathrm{HH}$ and $\mathrm{MH}$ groups were mainly attributed to the high variability of phytoplankton abundance of Grande Lake and Archibarca Lake, respectively. Differences between lakes' groups were statistically significant for Bacillariophyceae (KW test, $Z=11.56, P=0.003$, MW test $\mathrm{SH}-\mathrm{HH}, P=0.008)$ and Euglenophyceae (KW test, $Z=15.49, P=0.0004$, MW test $\mathrm{SH}-\mathrm{HH} P=0.009$ and $\mathrm{MH}-\mathrm{HH} P=0.002$ ). The other groups of phytoplankton did not show statistically significant differences among groups $(P>0.05)$.

A total of 21 zooplankton species were registered among the different lakes sampled, being Rotifera the best represented in richness (ten species registered), and followed by Cladocera (six species) and Copepoda (five species). HH lakes were mainly dominated by Rotifera 

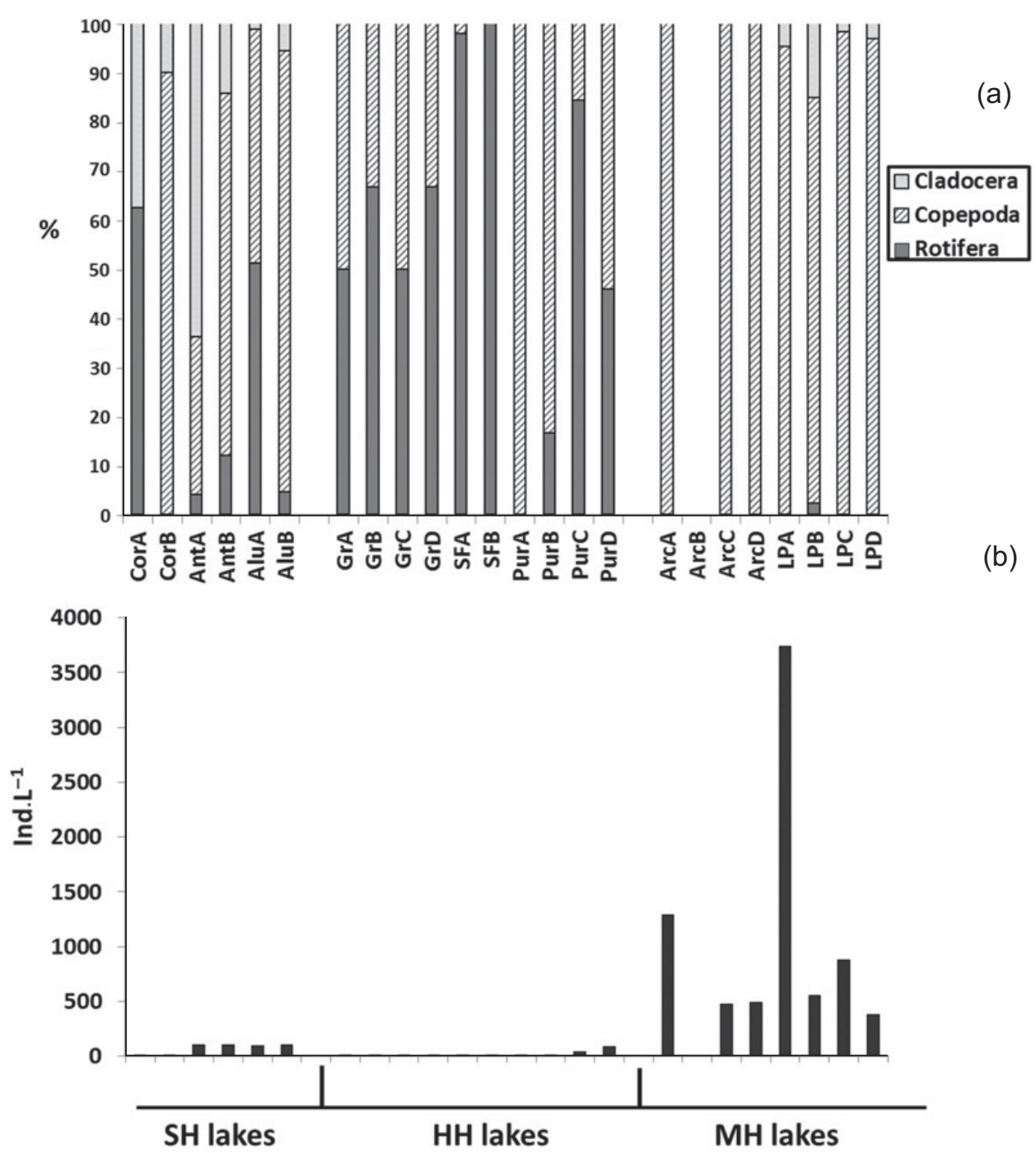

Fig. 4. Percentage of contribution of each zooplankton group (a) and total abundance (ind. $\mathrm{L}^{-1}$ ) registered in each sampling point (b).

( $>51 \%$ with the exception of two replicas), and the $\mathrm{MH}$ group was dominated by Copepoda ( $>85 \%$ of total abundance). SH lakes did not demonstrate clearly dominant taxa (Fig. 4(a)).

SIMPER analysis confirmed those differences found in the relative abundance of species among lakes, being these differences statistically significant and greater than $70 \%$ in all cases (Table 2). The SH lakes were characterized by the presence of Alona sp. (Cladocera), Lecane luna (Müller), L. closterocerca (Schmarda) (Rotifera) and Boeckella gracilis (Daday) (Copepoda). The HH lakes were mainly characterized by Cephalodella sp., Brachionus pteronioides (Rousselt), B. plicatilis (Müller) (Rotifera) and a no identified Harpacticoidea Copepoda species (Copepoda), while the MH group was mainly defined by Boeckella poopoensis (Marsh) (Copepoda). Spearman correlations showed that zooplankton richness was negatively linked with salt concentration (Rho $=-0.491 P=0.015)$ and altitude $(-0.624 P=0.001)$, but positively correlated with phytoplankton richness $(\mathrm{Rho}=0.584 P=0.003)$.
The greatest abundance of zooplankton was found in MH lakes with an average value 975 ind. $\mathrm{L}^{-1}(\mathrm{CV}=121)$, whereas $\mathrm{SH}$ and $\mathrm{HH}$ lakes registered 69 ind. $\mathrm{L}^{-1}(\mathrm{CV}=85)$ and 15 ind. $\mathrm{L}^{-1}(\mathrm{CV}=186)$, respectively. The dispersion of data observed in $\mathrm{MH}$ is attributable to the high density values obtained in Archibarca. The differences in zooplankton abundance between lake types were statistically significant (KW test, $Z=10.99, P=0.004$ ) between $\mathrm{SH}-$ HH (MW test, $P=0.023$ ) and SH-MH lakes (MW test, $P=0.008$ ) (Fig. 4(b)). These differences were statistically significant for all groups of zooplankton considered. Rotifera (KW test, $Z=8.52, P=0.014$ ) showed differences between SH-MH (MW test, $P=0.022$ ) and HH-MH (MW test, $P=0.006$ ). Differences for Copepoda and Cladocera abundance, were also statistically significant (KW test, $Z=10.43, P=0.005$ and $Z=11.93, P=0.0026$, respectively) between $\mathrm{SH}-\mathrm{MH}$ and $\mathrm{HH}-\mathrm{MH}$ lakes for Copepoda (MW test, $P=0.020$ and 0.0074 , respectively) and between $\mathrm{SH}-\mathrm{HH}$ and $\mathrm{HH}-\mathrm{MH}$ lakes for Cladocera (MW test, $P=0.0002$ and 0.017 , respectively). 

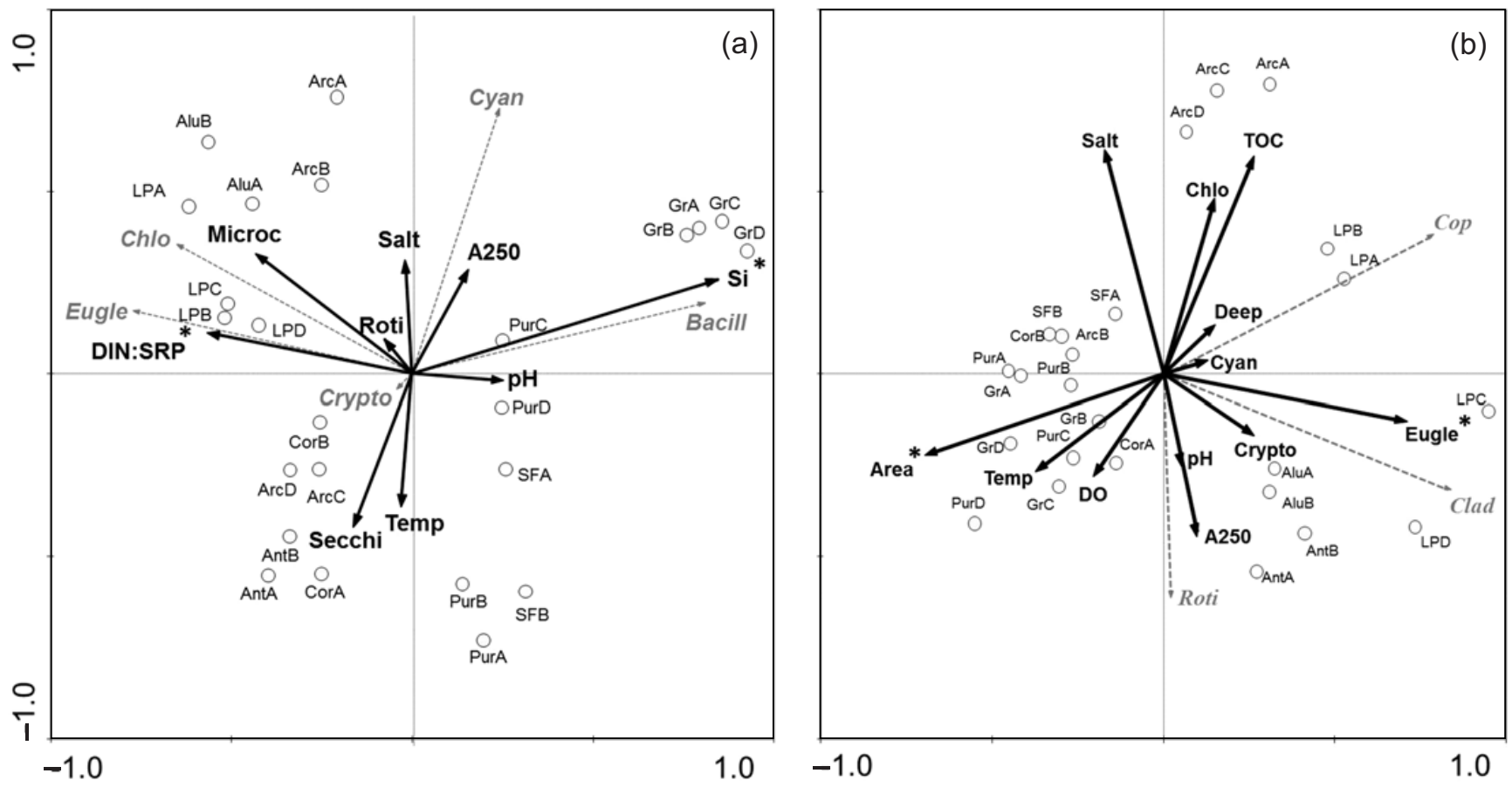

Fig. 5. RDA plot for phytoplankton (a) and zooplankton (b) (1st and 2nd component in both cases). Explanatory variables and response variables are named as in Figure 2. In (a) microcrustacean density (Cladocera + Copepoda) (Microc) and in (b) the lake area (area) and dissolve organic matter $\left(A_{250}\right)$ were also included as explanatory variable. Statistically significant explicative variables are indicated $(*)$.

\section{Factors controlling plankton abundance}

RDA analyses demonstrated that both phytoplankton and zooplankton abundance were arranged according to a gradient of environmental variables. As for phytoplankton, RDA analysis allowed to explain $70.7 \%(F=3.141$, $P=0.002)$ of total variance. The first axis explained $57.4 \%$ of that total variance, and discriminated $\mathrm{HH}$ lakes of the rest of lakes (SH and MH lakes) (Fig. 5(a)). The second axis explained $19.6 \%$. Phytoplankton structure was significantly explained by two variables: Si $(F=9.885, \quad P=0.002)$ and DIN:SRP $(F=3.794$, $P=0.012)$. The other variables included in the analyses did not show any correlation to phytoplankton abundance $(P>0.05)$. Bacillariophyceae, the most abundant group, was positively associated with $\mathrm{Si}$ in $\mathrm{HH}$ lakes; and negatively associated with increasing values of DIN:SRP. On the other hand, Euglenophyceae and Chlorophyceae were positively associated with DIN:SRP (Fig. 5(a)).

The RDA for zooplankton explained the $75.7 \%$ $(F=2.849, P=0.016)$ of total variance, with the first axis explaining $70.8 \%$ of that total variance and the second $22.2 \%$. Two variables were responsible of the high percentage of explanation obtained: Euglenophyceae $(F=8.084, \quad P=0.002)$ and lake area $(F=7.619$, $P=0.004)$. The rest of variables used in the analysis were not statistically significant $(P>0.05)$. Cladocera and Copepoda were positively associated with the abundance of Euglenophyceae in MH lakes. Both microcrustaceans, however, were negatively associated with the lake area. On the other hand, Rotifera showed a positive association with $A_{250}$; not being this association statistically significant $(F=0.901, P=0.398)($ Fig 5(b)).

\section{Discussion}

\section{Salinity and altitude as controlling factors of plankton composition}

The presence of a population in a habitat is linked with a complex combination of factors which, if the tolerance limits for a factor are exceeded, then may result in the exclusion of several species (Hammer et al., 1983). In our study, zooplankton species richness demonstrated to be negatively related to salinity $(\mathrm{Rho}=-0.491, P=0.015)$, a pattern that has been widely descripted by previous authors (Timms, 1993; Cooper and Wissel, 2012), since a few number of species are able to tolerate an increase in salt concentration. The presence of the genera Brachionus, Cephalodella and Boeckella in $\mathrm{HH}$ and $\mathrm{MH}$ lakes is consistent with previous founding, since these genera are greatly adapted to high salt concentrations (Derry et al., 2003; Battauz et al., 2013). Phytoplankton species richness, however, did not show a clear association with salinity (Rho $=-0.350, P=0.092)$ as was expected. In $\mathrm{HH}$ lakes, phytoplankton was mainly dominated by Bacillariophyceae with the genera Navicula and Surirella as dominant. Saros and Fritz (2000) indicate that 
moderate levels of ions in water can favour nutrient up take and frustule production in several diatom species, being the physiological mechanisms yet underterminated. $\mathrm{MH}$ lakes, which were in fact, the lakes with higher concentration of salt, were mainly dominated by euglenoids such as E. acus and T. volvocina. The presence of euglenoids in $\mathrm{MH}$ lakes have been reported by other authors (Hammer et al., 1983; Padisák and Dokulil, 1994; Mirande and Traccana, 2009) indicating that many algal species of Euglenophyceae could be euryhaline or have a broad salinity tolerance.

Similarly, both zooplankton and phytoplankton richness demonstrated to be negatively related to altitude (Rho $=-0.624, P=0.001$ and Rho $=-0.582, P=0.003$, respectively). Despite the fact that we have not measure radiation, it is a fact that UV radiation increases with altitude, and this has a negative effect on plankton, causing significant inhibition of phytoplankton photosynthesis and affecting negatively the activity, growth and survival of zooplanktonic organisms (Sommaruga, 2001). In accordance to this, in those lakes with higher altitude, B. poopoensis (a calanoid copepod species which is highly red pigmented when inhabits areas with high UV radiation exposure) presented the highest abundance. With respect to phytoplankton, it was not found a clear explanation of why species richness was negatively associated with altitude. Studies made in the Alps, have demonstrated that flagellate species like found in this study (euglenoids and cryptophytes), occupy the deepest water layers during the daytime to prevent photo-oxidation by an excessive UV radiation exposure (Sommaruga, 2001). In our study, euglenoids and cryptophytes were dominant in the assemblage of those lakes with higher altitude and depth, but depth of these lakes cannot be compared with found in the Alp lakes. By this reason, specific efforts should be made in the future to clarify the pattern observed in these lakes.

\section{Controlling factors of plankton abundance in the salinity gradient}

Our results indicated that both groups of plankton were mainly influenced by Bottom-Up forces. With respect to phytoplankton, we observed that DIN:SRP and TN:TP ratios were low in comparison with those frequently observed in lowland shallow lakes, where higher quantities of organic matter are available for its degradation and subsequent nutrients liberation into the water column (Morales Baquero et al., 1999; Schelske et al., 1999). In addition, both nutrient ratios were below 1:16 (except TN:TP in Antofagasta Lake) which would suggest a N limitation for phytoplankton (Redfield et al., 1963). Zooplankton and flamingos did not display an effect on phytoplankton abundance (absence of Top-Down effects). With respect to zooplankton, as we will see below, it also demonstrated to be mainly controlled by resource availability (DOM and phytoplankton); not being predation by $P$. chilensis an important descriptor of the arrangement.
The absence of Top-Down effects and predominance of Bottom-Up forces in saline water systems, have been experimentally proved by Salms et al. (2009) in the US saline lakes and Rejas et al. (2012) in Bolivia (South America), being this study a field evidence of the relevance of Bottom-Up as a main structuring factors of plankton abundance in these extreme environments.

SH lakes presented the lowest phytoplankton density values, but they had the widest representation of phytoplankton groups. This pattern may be associated with less extreme conditions which these lakes presented, since they had the lowest salt concentration $\left(1.40 \pm 0.72 \mathrm{~g} . \mathrm{L}^{-1}\right)$, the lowest altitude (with exception of Cortaderas Lake) and the highest ratios of DIN:SRP and TN:TP $(1.20 \pm 0.42$ and $8.27 \pm 8.46$, respectively). According to Williams (2002), these lakes are considered freshwater lakes, an in our study, they were associated with a predominance in abundance of Chlorophyceae and Euglenophyceae (see Fig. 3(b)), two groups which are frequently found in freshwater lakes in lowland areas during the warm season (García de Emiliani, 1997; Stevict et al., 2013).

The association of microcrustaceans to $\mathrm{SH}$ lakes with high abundance of Chlorophyceae and Euglenophyceae suggests that predation by zooplankton is not a relevant factor for phytoplankton abundance in these water systems. Microcrustaceans were poorly represented in abundance, but they could have an effect on phytoplankton biovolume, which was not considered in our study. In terms of quantity, however, their positive correlation with Chlorophyceae and Euglenophyceae, indicates that these algae were controlling the abundance of microcrustaceans.

With respect to zooplankton, Rotifera was the group best represented in SH lakes where high DOM concentrations were obtained. DOM is frequently associated with high bacteria production (Kritzberg et al., 2004), which could be a key source of food for rotifers (Arndt, 1993). Moreover, a high DOM concentration may attenuate the effects of UV radiation, especially in transparent lakes, such as was the case, probably favouring Rotifera (Laurion et al., 2000). Further specific studies will allow us to discriminate the importance of DOM concentration in Rotifera distribution in these kinds of lakes.

HH lakes had the highest total phytoplankton abundance, mainly Bacillariophyceae (diatoms), which were highly correlated with $\mathrm{Si}$ concentration. Diatoms are dependent on Si for their frustule production as we said, and moreover, a moderate salt concentration could favour Si uptake (Saros et al., op cit.). The low DIN:Si ratios found, suggest that diatoms would be limited by $\mathrm{N}$ availability but not by $\mathrm{Si}$ in these water bodies (Redfield et al., $o p$. cit.). In addition, the negative relation found between diatoms abundance and DIN:SRP is consistent with the high abundance of Bacillariophyceae registered in these lakes, since in general, algae consume 16 mole of $\mathrm{N}$ per mole of $\mathrm{P}$, and this would make lower the ratio in those lakes with high phytoplankton density. Flamingos, especially $P$. jamesi and $P$. andinus mainly 
feed on Bacillariophyceae, and were abundant in $\mathrm{HH}$ lakes, especially in Grande Lake (Mascitti and Kravett, 2002). Our results, however, did not indicate the birds' filter-feeding activity was important descriptors of phytoplankton abundance. This effect however, could be more local and having a restricted measurable effect.

With respect to zooplankton, it was poorly represented in $\mathrm{HH}$ lakes only demonstrating a negative association with lakes' area. In this respect, some hypothesis should be tested: low-density values could be related to low food availability (mainly diatoms which could pass the gut without being affected) or an effect of bird predation which should be tested specifically with an experimental design.

Finally, in $\mathrm{MH}$ lakes the high $\mathrm{Si}$ concentration (see Table 1) was correlated with a high density of Bacillariophyceae and Euglenophyceae. The co-dominance of Euglenophyceae-Bacillariophyceae in these saline environments could be explained by the resistance of both algae groups to high salt concentrations (Padisák and Dokulil, 1994; Mirande and Traccana, 2009), and a greater nutrient availability observed. Copepoda and especially the calanoid $B$. poopoensis was dominant in MH lakes (between 477 and 1293 ind. $\mathrm{L}^{-1}$ ). This species can survive in environments where salinity ranges from 1 to 90 g. $\mathrm{L}^{-1}$, and flourishes between 45 and 90 g. $\mathrm{L}^{-1}$ (De los Ríos and Crespo, 2004) which is consistent with salinity values found in these lakes. Some cladoceran taxa were also present in these lakes, but at low densities, corroborating similar findings in previous studies (Timms, 1993; Echaniz et al., 2006). The high and positive correlation between Copepoda and Euglenophyceae also suggests that Bottom-Up forces were the major factors which were controlling $B$. poopoensis abundance in these lakes.

\section{Conclusions}

Our results indicate that salinity and altitude are important stressors for plankton richness, controlling by the way, which species can survive in such extreme locations. Plankton abundance seems to be controlled by BottomUp forces, not being predation a relevant factor for any group of plankton.

Acknowledgements. Field surveys were supported by the Grupo de Conservación de Flamencos Altoandinos (GCFA). We thank to M. Mosqueira for his assistance in the field. Thanks are also extended to M. Devercelli and J.C Paggi who improved this manuscript with their comments.

\section{References}

Ahlstrom E.H., 1940. A revision of the Rotatorian genera Brachionus and Platyias with descriptions of one new species and two new varieties. Bull. Am. Mus. Nat. Hist., 77, 143-148.
Alekseev V.R., 2002. Copepoda. In: Fernando, C.H. (ed.), A Guide to Tropical Freshwater Zooplankton, Backhugs Publ, 123-188.

Álvarez Blanco I.C., Cejudo Figueiras I., De Godos I., Muñoz R. and Blanco S., 2011. Las diatomeas de los salares del Altiplano boliviano: singularidades florísticas. Bol. R. Soc. Esp. Hist. Nat. Secc. Biol., 105, 67-82.

APHA 1992. Standard Methods for the Examination of Water and Wastewater, American Public Health Association, Washington.

Arnd H., 1993. Rotifers as predators on components of the microbial web (bacteria, heterotrophic flagellates, ciliates) - a review. Hydrobiologia, 255, 231-246.

Battauz Y., José de Paggi S., Romano M. and Barbaeris I., 2013. Zooplankton characterization of the Pampean saline shallow lakes, habitat of the Andean Flamingoes. J. Limnol., 72, 531-542.

Boyle T.P., Caziani S.M. and Walermire R.G., 2004. Landsat TM inventory and assessment of waterbird habitat in the southern altiplano of South America. Wetl. Ecol. Manage., $12,563-573$.

Collier K.J., 1987. Spectrophotometric determination of dissolved organic carbon in some South Island streams and rivers (note). J. Mar. Freshw. Res., 21, 349-351.

Conzonno V., 2009. Materia orgánica. Sustancias húmicas. In: Edulp (ed.), Limnología Química (1 ra edn), Universidad Nacional de La Plata, 191-209. (La Plata).

Cooper R.N. and Wissel B., 2012. Interactive effects of chemical and biological controls on food-web composition in saline prairie lakes. Aquat. Biosyst., 8-29.

Dangaus N.V., 1976. Descripción sistemática de los parámetros morfométricos considerados en las lagunas pampásicas. Limnobios, 1, 35-59.

De Haan H. and De Boer T., 1987. Applicability of light absorbance and fluorescence as measures of concentration and molecular size of dissolved organic carbon in humic lake Tjeukemeer. Water Res., 21, 731-734.

De los Ríos P. and Crespo J., 2004. Salinity effect on the abundance of Boeckella poopoensis (Copepoda, Calanoida) in saline ponds in the Atacama Desert, northern Chile. Crustaceana, 77, 417-423.

Derry A., Prepas E. and Hebert P., 2003. A comparison of zooplankton communities in saline lake water with variable anion composition. Hydrobiologia, 505, 199-215.

Drago E. and Quirós R., 1996. The hydrochemistry of the inland waters of Argentina: a review. Int. J. Salt Lake Res., 4, 315-325.

Echaniz S., Vignatti A., José de Paggi S., Paggi J.C. and Pilati A., 2006. Zooplankton seasonal abundance of South American saline shallow lakes. Int. Rev. Hydrobiol., 91, 86-100.

García de Emilliani M.O., 1997. Effects of water level fluctuations on phytoplankton in a river-floodplain lake system (Parana River, Argentina). Hydrobiologia, 357, 1-15.

Hammer U.T., 1986. Saline Lake Ecosystems of the World, Junk Publishers, Dordrecht, Holland.

Hammer U.T., Shamess J. and Haynes R.C., 1983. The distribution and abundance of algae in saline lakes of Saskatchewan, Canada. Hydrobiologia, 105, 1-26.

Hilton J. and Rigg E., 1983. Determination of nitrate in lake water by the adaptation of the hydrazine-copper reduction method for use on a discrete analyser: performance statistics 
and an instrument-induced difference from segmented flow conditions. Analyst, 108, 1026-1028.

Kieffer L.A., 1981. Evaluación de la materia orgánica disuelta. Rev. Asoc. Cienc. Nat. Litoral, 12, 88-95.

Kirk J.T.O., 1994. Light and Photosynthesis in Aquatic Ecosystems, Cambridge University Press, Cambridge, $401 \mathrm{p}$.

Komarék J. and Anagnostidis K., 1999. Cyanoprokariota. 1. Chroococcales. In: Ettl H., Gärtner G., Heynig G. and Mollenhauer D. (eds.), Subwasserflora von Mitteleuropa.19. Gustav Fisher, Jena, Stutgart.

Komárek J. and Anagnostidis M., 2005. Cyanoprokaryota 2. Teil/ 2nd Part: Oscillatoriales. In: Büdel B., Krienitz L., Gärtner G. and Scnagerl M. (eds.), Süsswasserflora von Mitteleuropa 19/2, Elsevier/Spektrum, Heidelberg.

Komárek J. and Fott B., 1983. Chlorophyceae, chlorococcales. In: Huber-Pestalozzi, G. (ed.), Das Phytoplankton des Sdwasswes. Die Binnenggewasser, vol. 16(5). Schweizerbart'sché Verlagbuchhandlung, Stuttgart.

Korrínek V., 1981. Diaphanosoma birgei n. sp (Crustacea, Cladocera), a new species from America and it's widely distribution species Diaphanosoma birgei ssp. L acustrisn ssp. Can. J. Zool., 59, 1115-1121.

Korrínek V., 2002. Cladocera. In: Fernando C.H. (ed.), A guide to tropical freshwater zooplankton, Backhuys Publ, the Netherlands, 69-122.

Korovchinski N.M., 1992. Sididae and Holopedidae (Crustacea: Daphniiformes). Guides to identification of the microinvertebrates of the continental waters of the world, SPB Academic Publ., The Hage, 82 p.

Koste W., 1978. Rotatoria. Die Radertiere Mitteleuropas, Gebruder Borntraeger, Berlin, 673 p.

Krammer K. and Lange-Bertalot H., 1991. Bacillariophyceae. 3. Teil Centrales, Fragilariaceae, Eunotiaceae. In: Ettl H., Gerloff J., Heynig H. and Mollenhauer D. (eds.), Süsswasserflora von Mitteleuropa, Gustav Fischer Verlag, Stuttgart.

Kritzberg E.S., Cole J.J., Pace M.L., Granéli M. and Bade D.L., 2004. Autochthonous versus allochthonous carbon sources of bacteria: results from whole-lake $13 \mathrm{C}$ addition experiments. Limnol. Oceanogr., 49, 588-596.

Laurion I., Ventura M., Catalan J., Psenner R. and Sommaruga R., 2000. Attenuation of ultraviolet radiation in mountain lakes: factors controlling the among- and within-lake variability. Limnol. Oceanogr., 45, 1274-1288.

Lepš J. and Šmilauer P., 1998. Multivariate Analysis of Ecological Data. Faculty of Biological Sciences, University of South Bohemia Ceské Budejovice, Czech Republic, 110 p.

Locascio de Mitrovic C.A., Villagra de Gamundi A., Juárez J. and Ceraolo M., 2005. Características limnológicas y zooplancton de cinco lagunas de la Puna - Argentina. Rev. Bol. Ecol. Cons. Amb., 40, 12-26.

Maidana N.I., Seeligmann C.T. and Morales M.R., 2009. Bacillariophyceae del Complejo Lagunar Vilama (Jujuy, Argentina). Bol. R. Soc. Esp. Hist. Nat. Secc. Biol., 44, 257-271.

Marconi P., 2010. Técnicas de monitoreo de condiciones ecológicas en la Red de Humedales de Importancia para la Conservación de Flamencos Altoandinos. In: Marconi P. (ed.), Manual de técnicas de monitoreo de condiciones ecológicas para el manejo integrado de la red de humedales de importancia para la conservación de flamencos altoandinos, Fundación YUCHAN, Argentina, 8-14.
Mascitti V. and Kravetz F.O., 2002. Bill morphology of South American flamingos. Condor, 104, 73-83.

Meehl G.H., Arblaster J.M. and Tebaldi C., 2005. Understanding future patterns of increased precipitation intensity in climate model simulations. Geophys. Res. Lett., 32, 18719.

Mirande V. and Tracanna B., 2009. Estructura y controles abióticos del fitoplancton en humedales de altura. Ecol. Austr., 19, 119-128.

Morales Baquero R., Carrillo R., Reche I. and Sánchez-Castillo P.M., 1999. Nitrogen-phosphorus relationship in high mountain lakes: effects of the size of catchment basins. Can. J. Fish. Aquat. Sci., 56, 1809-1817.

Padisák J. and Dokulil M., 1994. Meroplankton dinamic in a saline, turbulent, turbid shallow lake (Neusiedlersee, Austria and Hungary). Hydrobiologia, 289, 23-42.

Psenner R., 2002. Alpine waters in the interplay of globa change: complex links - simple effects? In: Steininger K.W. and Weck-Hannemann H. (eds.), Global Environmental Change in Alpine Region. New Horizons in Environmental Economics, Edward Eldgar, Cheltenham, UK, Northampton, MA, USA, $271 \mathrm{p}$.

Redfield A.C., Ketchum B.H. and Richards F.A., 1963. The influence of organisms on the composition of seawater. In: Hill, M.N. (ed.), The Sea. Vol. 2. Interscience Publishers, John Wiley, New York, pp. 26-77.

Rejas D., Valverde C. and Fernández C.E., 2012. Limitación por nutrientes y pastoreo como factores de control de las densidades de bacterias y algas planctónicas en una laguna altoandina (Cochabamba, Bolivia). Rev. Bol. Ecol. Cons. Amb., 30, 01-12.

Salms C.R., Saros J., Martin C.S. and Erickson J.M., 2009. Patterns of seasonal phytoplankton distribution in prairie saline lakes of the northern Great Plains (U.S.A.). Saline Syst., $5,1-13$.

Saros J.E. and Fritz S.E., 2000. Changes in the growth rates of saline-lake diatoms in response to variation in salinity, brine type, and nitrogen form. J. Plankton Res., 22, 1071-1083.

Schelske C.L., Aldridge F.J. and Kenney W.F., 1999. Assessing nutrient limitation and trophic state in Florida lakes In: Reddy K.R., O'connor G.A. and Schelske C.L. (eds.), Phosphorus Biogeochemistry in Subtropical Ecosystems, Lewis Publishers, Boca Rotón, 321-342.

Seeligmann C., Maidana N.I. and Morales M., 2008. Diatomeas (Bacillariophyceae) de humedales de altura de la provincia de Jujuy-Argentina. Bol. R. Soc. Esp. Hist. Nat. Secc. Biol., 43, $1-17$.

Sommaruga R., 2001. The role of solar UV radiation in the ecology of alpine lakes. J. Photochem. Photobiol. B, Biol., 62, 35-42.

Stevict F., Mihaljevic M. and Spoljaric D., 2013. Changes of phytoplankton functional groups in a floodplain lake associated with hydrological perturbations. Hydrobiologia, 709, 143-158.

Stewart A.J. and Wetzel R.G., 1981. Asymmetrical relationships between absorbance, fluorescence, and dissolved organic carbon. Limnology and Oceanography, 26, 590-597.

Tell G. and Conforti V., 1986. Euglenophyta pigmentadas de Argentina. In: Cramer (ed.), Bibliotheca Phycologica, Berlin, Germany.

Timms B.V., 1993. Saline lakes of the Paroo, inland New South Wales, Australia. Hydrobiologia, 267, 269-289.

Tolotti M., Thies M., Cantonati M., Hansen C. and Thaler B., 2006. Flagellate algae (Chrysophyceae, Dinophyceae, 
Cryptophyceae) in 48 high mountain lakes of the Northern and Southern slope of the Eastern Alps: biodiversity, taxa distribution and their driving variables. Hydrobiologia, 502, 331-348.

Utermöhl H., 1958. Zur Vervollkommnung der quantitativen Phytoplankton-Methodik. Mitt. Int. Verein. Limnol., 9, $1-38$.

Van den Hoek C., Mann D.G. and Jahns H.M., 1995. Algae: an Introduction to Phycology, Cambridge University Press, UK.
Williams W.D., 2002. Environmental threats to salt lakes and the likely status of inland saline ecosystems in 2025. Environ. Conserv., 29, 154-167.

Williams W.D., Boulton A.J. and Taaffe R.G., 1990. Salinity as a determinant of salt lake fauna: a question of scale. Hydrobiologia, 197, 257-266.

Zalocar de Domitrovic Y. and Maidana N.I., 1997. Taxonomic and ecological studies of the Parana River diatom flora (Argentina). In: J. Cramer (ed.). Biblioteca diatomológica, Stuttgart, Berlin. 